\title{
Otorhinolaryngology practice in the rural area
}

\author{
Kırsal alanda kulak burun boğaz hekimliği \\ Ozan Gökdoğan', Hacer Baran', Taliye Çakabay', Burak Karabulut', Tolgahan Çatı² \\ ${ }^{1}$ Department of Otorbinolaryngology, Ardahan Government Hospital, Ardahan, Turkey \\ ${ }^{2}$ Department of Otorbinolaryngology, Bozyaka Training and Research Hospital, Izmir, Turkey
}

\begin{abstract}
Objective: In this study, our aim was to evaluate statistically demographic distribution, presenting complaints, requested examinations, prescribed drugs, and follow-up recommendations related to the patients who applied to the otorhinolaryngology outpatient clinics in a rural area of Turkey.

Methods: Examinations, and treatments applied by three physicians on separate days, and at different times of the day in outpatient clinics were recorded.

Results: When the complaints of the patients were analyzed, upper respiratory tract infections were observed as the most frequent causes of hospital referrals. It has been indicated that any tests had not been required from majority of the patients, and if required, most of them were audiological tests. Prescriptions were written for the treatment of upper respiratory tract infections, and follow-up visits were not recommended for half of the patients.

Conclusion: As deduced from this study, primary, and secondary health care services provide $1 / 3$, and $2 / 3$ of otorhinolaryngology services in the rural areas of Turkey.
\end{abstract}

Keywords: Rural area, otorhinolaryngology practice.

In dwelling units with a population of more than 20,000 individuals are considered as cities, and other settlements are recognized as rural areas. ${ }^{[1]}$ According to the data of address-based population registration system (2012), the total population of the city of Ardahan is 106,643 while population of city-town centers $(37,522)$, districts, and villages $(69,121)$ have been also determined. ${ }^{[2]}$ Population of the city center of Ardahan has been determined as 18,298. Seventeen percent of the total population is living in the

\section{Özet}

Amaç: Bu çalışmada, Türkiye'nin kırsal kesimindeki KBB polikliniğine başvuran hastaların demografik dağılımları, başvuru şikayetleri, istenen tetkikler, yazılan ilaçlar ve kontrol önerilerinin istatistiksel değerlendirilmesi amaçland.

Yöntem: KBB polikliniğinde üç ayrı hekim tarafindan değişik gün ve saatlerde yapilan muayene ve tedaviler kayıt edildi.

Bulgular: Hastaların başvuru şikâyetleri incelendiğinde en sık üst solunum yolları enfeksiyonları nedenleri ile başvurmuş olduğu gözlendi. Hastaların büyük kısmından herhangi bir tetkik istenmediği ve istenen tetkiklerin büyük kısmını da odyolojik tetkikler olduğu belirlendi. Hastalara yazılan reçetelerin de üst solunum yolları enfeksiyonlarına yönelik olduğu saptanırken, tedavi sonrası hastaların yarısına da kontrol önerilmemiş olduğu görüldü.

Sonuç: Türkiye'de kırsal kesime sunulan KBB hizmetlerinin yaklaşık 1/3'lük kısmının 1. basamak sağlık hizmetlerini, 2/3'lük kısmının ise 2. basamak sağlık hizmetlerini içerdiği gözlenmiştir.

Anahtar sözcükler: Kırsal alan, kulak burun boğaz hekimliği.

city center of Ardahan. If we add villages affiliated to the city center, this rate amounts to $35 \%$ of the total population. Since majority of the population is living in the districts, and villages, and the population of the city center still remains 20,000 people, it is possible to consider Ardahan as a rural area.

The Law No. 5258 for the Implementation of Family Medicine pilot scheme was enacted in Great National Assembly of Turkey in 11.24.2004. ${ }^{[3]}$ Family Medicine
Correspondence: Tolgahan Çatlı, MD. Departmeny of Otorhinolaryngology, Bozyaka Training and Research Hospital, Izmir, Turkey. e-mail: tcatli80@hotmail.com

Received: October 17, 2014; Accepted: November 12, 2014
Online available at: www.jmedupdates.org doi: 10.2399/jmu.2014003007 QR code: 
Scheme was firstly implemented in September 15, 2005 in Düzce, which was the first pilot city of Turkey. As a result of stepwise transition, implementation of family medicine was started on December 13, 2010 in all cities. The specialty of otorhinolaryngology is a discipline of medicine interested in head and neck diseases. It is one of the oldest disciplines of the medical practice, and its diseases are one of the most frequent causes of referrals to the physicians. Majority of the applications to the health care services consists of upper respiratory tract infections. ${ }^{[4]}$ Serious problems experienced regarding ultrastructure, and manpower complicate provision of preventive, and therapeutical health services in Eastern, and Southeastern Anatolia Regions. Therefore, most of the patients apply to secondary or even tertiary health care services, rather than primary care services. Therefore, secondary health care services are assuming the tasks of both primary, and secondary care services which leads to heavy patient circulation. ${ }^{[5]}$

In the literature, a study concerning distribution of patients, and admission complaints among health services in the rural areas have not been encountered. The aim of this study is to evaluate demographic distribution, admission complaints, required examinations, prescribed drugs, and their distribution, and follow-up recommendations.

\section{Materials and Methods}

A total of 385 patients who applied to otorhinolaryngology outpatient clinic of Ardahan Government Hospital between September and October 2012 were evaluated. Since the survey study was performed in the rural areas where a tradition of settling on uplands during summer, and migrating to warmer climates during winter months is still prevailing, September, and October months were selected for the implementation of the survey study. The study was planned, and the approval of the Ethics Committee of Erzurum Atatürk University Faculty of Medicine The Institute of Non-Pharmacological Investigations (regulation \#17 dated September 27, 2012) was obtained. Working hours were randomized within office hours. All otorhinolaryngology specialists working in the Ardahan Government Hospital were randomized in the study.

Self-assessment forms were constructed to evaluate the patients before the study. Gender, ages, and barcodes of the patients on the waiting list were attached on these selfassessment forms. The first column of the form which contained the most frequently encountered 16 complaints of the patient, and the 17th option which indicated other causes were filled up by the physician who took the med- ical histories of the patients. The most frequent $16 \mathrm{com}-$ plaints were prepared based on clinical practice, and if any tests were not required at the second stage, the item "any test was not required" was ticked, and if required, then the most requested 14 tests were indicated, and the 15 th item was marked as "other". At the 3rd stage if any prescription was not given then the number ' 0 ' was ticked, and the most prescribed 13 group drugs were marked as "the basic group" without specifying any name of the drug, and ticked as the 14th option. Lastly, if the patients were not called for a return visit it was indicated as ' 0 ', if they were called for a return visit then the day of their scheduled visit day was indicated in the form. As an additional data, the name of the examining physician and explanation of other marked items were also included.

\section{Results}

Mean age of the patients [males, $\mathrm{n}=172(44.7 \%)$, and females, $\mathrm{n}=213(55.3 \%)$ ] was 43.63 (range: 1 to 92 ) years. The most frequent admission complaint was sore throat $(20.6 \%)$. Other complaints in the order of decreasing frequency were ear ache $(17.2 \%)$, hearing loss $(13.9 \%)$, stuffy nose $(11.9 \%)$, hoarseness $(6 \%)$, tinnitus $(6 \%)$, coughing $(5.5 \%)$, other complaints $(5.1 \%)$, nosebleed $(4.6 \%)$, earwax $(4.4 \%)$, ear discharge (3.9\%), dizziness $(3.7 \%)$, headache $(2.9 \%)$, postnasal discharge $(2.7 \%)$, swelling on the neck $(2.7 \%)$, snoring (1.6\%), control examination $(1 \%)$, difficulty in swallowing $(0.3 \%)$, and nasal discharge $(0.3 \%)$. The item of other complaints were examined in detail, and foreign body in the nose (1.8\%), ear itching $(1.2 \%)$, jaw pain $(1.2 \%)$, skin infection $(0.3 \%)$, nosebleed $(0.3 \%)$, painful tongue $(0.3 \%)$, foreign body in the throat $(0.3 \%)$ were detected. Admission complaints of the patients were examined, and the patients were consulted to the outpatient clinic with one (65\%), or at least two $(35 \%)$ complaints. Of $35 \%$ who had at least 2 complaints, $31 \%$ of patients had 2 complaints, $3.8 \%$ of patients had 3 complaints, and $0.2 \%$ of patients had 4 complaints. Among patients with two complaints most frequently concomitancy of sore throat (14\%), and earache was observed. The symptoms of the patients with two complaints were as follows in decreasing order of frequency: hearing loss $(12.2 \%)$, stuffy nose $(10.2 \%)$, tinnitus $(8.4 \%)$, postnasal discharge $(7.6 \%)$, other $(7.1 \%)$, coughing $(5 \%)$, dizziness (4.2\%), earwax (3.8\%), nasal discharge (3.4\%), swelling on the neck $(2.9 \%)$, hoarseness $(2.5 \%)$, headache $(2 \%)$, snoring $(1.7 \%)$, and nosebleed $(1.2 \%)$ The most frequently observed concomitances were sore throat, earache, earache-hearing loss, hearing loss-tinnitus, earache-jaw pain, 
and postnasal discharge-nasal obstruction. Among patients with three complaints, hearing loss (18.1\%) was observed as the most frequent complaint, followed by coughing $(15.9 \%)$, sore throat $(13.6 \%)$, tinnitus (11.4\%), postnasal discharge (6\%), stuffy nose (6\%), earache $(6 \%)$, headache (4.5\%), ear discharge (4.5\%), nosebleed (2.5\%), and other complaints $(2.5 \%)$. The most frequently seen triple combinations were earache-hearing loss-tinnitus. In only one patient, concomitancy of four complaints was observed (earache-ear discharge-hearing loss-tinnitus).

When tests and examinations requested from the patients were analyzed, it was found out that the physicians did not require any tests from $78.4 \%$ of the patients. However, at least one test was required from $21.6 \%$ of the patients. Besides, audiogram was the most requested test $(60.5 \%)$. Other requested tests were as follows in order of decreasing frequency: thyroid function tests $(13.2 \%)$, cervical ultrasound $(8.8 \%)$, thyroid ultrasound $(5.5 \%)$, all haematological tests $(5.5 \%)$, PA chest X-ray $(2.2 \%)$, biochemical analyses (1.1\%), and other tests (3.2\%). When concomitancy of tests was scrutinized, most frequent ones were thyroid ultrasound-thyroid function tests, and all haematological tests-cervical ultrasonography were requested in combination. Prescriptions written at the end of the examination were also analyzed, and $31.4 \%$ of the patients were not given any medication. Majority $(68.6 \%)$ of the remaining patients was given at least one drug. The patients were prescribed one $(27.8 \%)$, two $(24.2 \%), 3$ $(13 \%)$, and $4(3.6 \%)$ drugs.

Drugs prescribed were also analyzed in detail, and it was seen that the antibiotics were the drugs most frequently prescribed to the patients $(21.5 \%)$ who admitted to the outpatient clinics. Then in order of decreasing frequency, ear drops (18.1\%), nasal steroids (16.8\%), analgesic-anti-inflammatory drugs $(13.7 \%)$, nasal decongestants $(11.1 \%)$, oral sprays and mouth rinses $(9.8 \%)$, proton pump inhibitors $(7.7 \%)$, antivertiginous agents $(7.7 \%)$, anthistaminics $(7.2 \%)$, onitments $(4.4 \%)$, leukotriene antagonists $(3.1 \%)$, thyroid replacement drugs $(0.4 \%)$, and other drugs $(7.3 \%)$ were prescribed. Detailed analysis of other drugs revealed nasal lavage solutions as the most frequently used drug followed by muscle relaxants, oral decongestants, lozenges, systemic steroids, mucolytics, and antitussives in decreasing order of frequency. Antibiotics were the most often (25.7\%) accompanied by analgesic and anti-inflammatory drugs. In combination with antibiotics decongestans $(19.11 \%)$, nasal steroids (16.9\%), mouth rinses (11.5\%), eardrops (7.1\%), and nasal lavage solutions $(3.5 \%)$ were used in decreasing frequen- cy. Analgesic and anti-inflammatory drugs were frequently used with anthistaminics (23.6\%) and nasal decongestants $(23.6 \%)$, mouth rinses (21.8\%), and muscle relaxants (12.7\%). Besides, $54.8 \%$ of the anthistaminic drug prescribed patients were also given nasal steroids. In combination with anthistaminics most often leukotriene antagonists $(16.6 \%)$ and proton pump $(9.5 \%)$ inhibitors were used. Anthistaminics were added to nasal steroids in $35.4 \%$ of the cases. However, leukotriene antagonists were used in combination with nasal steroids in $17 \%$ of the prescriptions. Anthistaminics, nasal steroids, and leukotriene antagonists were prescribed concurrently in $1.8 \%$ of the patients.

When the patients' compliance to follow-up visits, and the time of their return visits were analyzed, it was found that $49.9 \%$ of the patients were not called for a control visit. A small percentage (1.3\%) of the patients was hospitalized. The patients were called for a return visit, 1 (0.3\%), 2 (0.3\%), 3 (0.3), 7 (17.4\%), 14 (15.3\%), 20 $(2.6 \%), 30(12.5 \%)$, and 60 (0.3) days later. Follow-up visits were not recommended for the majority $(83.5 \%)$ of the patients for whom any drug was not prescribed. The patients who were not given any prescription were called for a follow-up visit 30 (6.6\%), 7 (2.5\%), and 14 (2.5\%) days later. Forty-two percent of the antibiotic-prescribed patients were not called for a follow-up visit. Other antibiotic-prescribed patients were called for a follow-up visit 14 (26.8\%), 7 (23.1\%), 20 (3.6\%), and 2 (1.2\%) days later. When these data were analyzed statistically, a correlation was observed between admission complaints, requested tests, and prescriptions written, while any correlation was not detected between patient's admission complaint(s), and scheduled time of the control visit.

\section{Discussion}

Although rural area has been described with various definitions, the term 'rural area' is used to define the regions with populations mostly living in villages, and towns rather than city center. According to the results of the 2012 census based on address-based population registration system of the Turkish Statistical Institute, only in 7 out of 81 cities of our country, the population of the city and town centers were lesser than those of districts, and villages. Among these 7 cities, city center of Ardahan has the least population. Only $17 \%$ of the population of Ardahan is living in city centers. Population of the city center and villages constitutes $35 \%$ of the population of Ardahan. In other words, since most of the population is 
living in districts and villages, population of the city center is under 20,000 people, we can consider Ardahan as the most typical example of the rural area. The people living in the rural areas have a tendency to consult to secondary care services rather than primary ones. This phenomenon is obviously related to sociocultural development. Very dispersed settlement of the people together with sociocultural underdevelopment, staged health care systems are intermingled. In this study, our aim was to analyse patients' demographic characteristics, complaints, tests and examinations requested from them, distribution of prescribed drugs, and follow-up times.

When literature is reviewed, we have not encountered any study investigating our objectives in rural areas, and city centers probably because of heavy patient circulation of the otorhinolaryngology outpatient clinics. In the present study, our emphasize on rural area is based on our viewpoint which asserts that diseases, and complaints observed in rural areas are at least partially different from those seen in the city center. Ticks in the external auditory canal whose details will be revealed in another study, and brucellosis, and tularaemia which we see more frequently in the regions where people mostly raising livestock demonstrate regional variations. Because of these reasons, rural area is emphasized. To prevent the impact of individualized drug selection on the study, the patients were evaluated equally by three physicians. The hospital evaluating the patients was in the city center, and daytime patients were coming from very remote regions. In order to obviate the impact of these factors on the study, at every hour of the day equal number of patients were included in the study. When results were analyzed, a female gender dominancy was observed (55.3\% vs $44.7 \%$ ) Median age of the patients was 43.63 (range: 1 to 92 ) years.

Sore throat (20.6\%), and earache (17.2\%) were the most frequently seen admission complaints of the patients. When headache $(2.9 \%)$ was added to these complaints, in accordance with the literature findings, most often upper respiratory tract infections were observed. Considering geographic conditions of the region, these are anticipated outcomes. Hearing loss (13.9\%), tinnitus (6\%), earwax (4.4\%), and ear discharge $(3.9 \%)$ were observed to be the most frequent complaints for the reason of application to the secondary medical centers. Among these, ticks in the external ear canal were more frequently observed complaint relative to other regions. Because of geographic conditions of the region such as higher altitude, and lower humidity, stuffy nose (11.9\%), hoarseness (6\%), coughing (5.5\%), nosebleed
(4.6\%), postnasal discharge (2.7\%), and nasal discharge $(0.3 \%)$ were significant admission complaints. Dizziness (3.7\%), swelling on the neck (2.7\%), snoring (1.6\%), control examination (1\%), and difficulty in swallowing $(0.3 \%)$ were among other observed complaints.

Tests requested from patients were scrutinized, and any tests were not observably demanded from $78.4 \%$ of the patients. Since most frequently upper respiratory tract infections were contemplated, this was an anticipated outcome. Thyroid function tests $(13.2 \%)$, cervical $(8.8 \%)$, and thyroid ultrasonographies $(5.5 \%)$ were requested for patients with neck swelling or those with a positive family history. Closeness of the region to the Eastern Black Sea Region can be enumerated among frequently seen causes of thyroid abnormalities. Complete hematological analysis (5.5\%), PA chest radiography (2.2\%), biochemical analyses $(1.1 \%)$, and other tests $(3.2 \%)$ were requested in respective percentages. Relatively lesser percentages of these examinations were thought to be related to the requirement of these tests by other outpatient clinics visited by the patient within the same day.

Prescriptions written at the end of the examination were scanned, and it was observed that for $31.4 \%$ of the patients, any treatment was not prescribed. Most of the latter group presumably consisted of the patients who did not need treatment or those treated in an external center, and applied to our clinic for control. The patients were prescribed antibiotics (21.5\%), nasal steroids (16.8\%), analgesic-anti-inflammatory drugs (13.7\%), nasal congestants $(11.1 \%)$, and oral sprays and rinses $(9.8 \%)$. For the treatment of the patients who mostly consulted with acute or chronic upper respiratory tract complaints, these types of drugs were used most frequently. Nasal steroids (16.8\%), anthistaminics (7.2\%), and leukotriene antagonists were frequently prescribed drugs for patients who were exposed to biomass due to geographic conditions, earning one's living from livestock farming, and use of dry animal dung fuel for warming. Other drugs used were ear drops $(8.1 \%)$, proton pump inhibitors $(7.7 \%)$, antivertiginous drugs $(7.7 \%)$, ointments $(4.4 \%)$, and thyroid replacement drugs $(0.4 \%)$. Nearly half $(49.9 \%)$ of the patients were not invited for a follow-up visit. Only $1.3 \%$ of the patients were hospitalized. The patients' return visits were most frequently scheduled 7, and then 14 days later. Since the patients were living far away from the hospital, and their inability to attend frequent follow-up visits, these time intervals were recommended for their follow-up visits. People living in uplands which partially sustain nomadic life 
resulted in prolongation of intervals between follow-up visits up to 60 days.

\section{Conclusion}

With this study three physicians evaluated 385 patients who applied to otorhinolaryngology outpatient clinics of Ardahan Government Hospital between September 2012 and October 2012 at different times of the day, and demographic data, admission complaints, requested tests, and patient follow-up periods were revealed. The patients consulted to the otorhinolaryngology clinics mostly with admission complaints of upper respiratory tract infections. It has been observed that any tests or examinations were not requested from most of the patients. Majority of requested examinations consisted of audiological tests. Prescriptions were mostly written for upper respiratory tract infections. After treatment, follow-up visits were not recommended for half of the patients. In conclusion, it has been observed that
$1 / 3$ of the patients were examined in the primary, and $2 / 3$ in the secondary health care institutions.

Conflict of Interest: No conflicts declared.

\section{References}

1. T.C. Tarım ve Köyişleri Bakanlığı Kırsal Kalkınma Planı ((2010-2013). Ankara: 2010. p. 14

2. TÜİK. Adrese dayalı nüfus kayıt sistemi (ADNKS) sonuçları [cited 2013 Apr 7]. Available from: http://www.tuik.gov.tr/ VeriTabanlari.

3. 09.12.2004 tarih ve 25665 sayılı Resmi Gazete.

4. Çă̆layan Ç, Hamzaoğlu O, Sevin E, Sondaş S. Kocaeli Üniversitesi Tıp Fakültesi eğitim sağlık ocakları bölgelerinde yaşayanlarda sağlık hizmetlerine başvurular etkileyen etmenler. Toplum Hekimliği Bülteni 2006;25:17-22.

5. Öcek Z, Soyer A. Birinci basamak sağlık hizmetleri birikimiz: 2000-2004 Türkiye fotoğrafi. Ankara: Türk Tabipleri Birliği Yayınları; 2007.

This is an open access article distributed under the terms of the Creative Commons Attribution-NonCommercial-NoDerivs 3.0 Unported (CC BYNC-ND3.0) Licence (http://creativecommons.org/licenses/by-nc-nd/3.0/) which permits unrestricted noncommercial use, distribution, and reproduction in any medium, provided the original work is properly cited.

Please cite this article as: Gökdoğan O, Baran H, Çakabay T, Karabulut B, Çatlı T. Otorhinolaryngology practice in the rural area. J Med Updates 2014;4(3):117-121. 